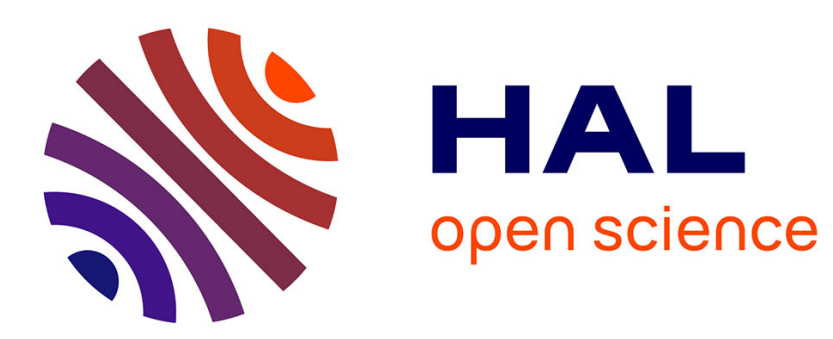

\title{
Wireless Community Networks: Towards a Public Policy for the Network Commons?
}

Primavera de Filippi, Félix Tréguer

\section{To cite this version:}

Primavera de Filippi, Félix Tréguer. Wireless Community Networks: Towards a Public Policy for the Network Commons?. Net Neutrality Compendium: Human Rights, Free Competition and the Future of the Internet, pp.261 - 270, 2015, 10.1007/978-3-319-26425-7_19 . hal-01382008

\section{HAL Id: hal-01382008 \\ https://hal.science/hal-01382008}

Submitted on 15 Oct 2016

HAL is a multi-disciplinary open access archive for the deposit and dissemination of scientific research documents, whether they are published or not. The documents may come from teaching and research institutions in France or abroad, or from public or private research centers.
L'archive ouverte pluridisciplinaire HAL, est destinée au dépôt et à la diffusion de documents scientifiques de niveau recherche, publiés ou non, émanant des établissements d'enseignement et de recherche français ou étrangers, des laboratoires publics ou privés. 


\title{
Wireless Community Networks: \\ Towards a public policy for the network commons? ${ }^{1}$
}

\author{
Primavera De Filippi ${ }^{2}$ \\ Félix Tréguer ${ }^{3}$
}

The history of communication technologies is populated with conflicts between centralization and decentralization. While many of these technologies started or have existed at some point of their development as a decentralized structure, often replacing older technological paradigms, nearly all progressively evolved into concentrated clusters of power as a result of industrialization and of the reaffirmation of state sovereignty, following a Schumpeterian process of "creative-destruction" (Wu, 2010). However, when the needs of citizens turn out to be systematically overlooked in existing power dynamics, decentralized initiatives may emerge as an attempt to disrupt the dominant hegemony and allow for the democratic re-appropriation of technology - a process that the philosopher Andrew Feenberg calls “subversive rationalization” (Feenberg, 1995).

In this paper, we focus on an ongoing - though too often neglected - phenomenon of decentralization in telecommunications networks. We show that current telecoms regulation significantly overlooks the contribution of community networks in fostering political and socio-economic objectives associated with broadband policy and we propose a number of policy recommendations to overcome this gap.

\footnotetext{
${ }^{1}$ This is an abridged version of another paper entitled "Expanding the Internet Commons : The Subversive Potential of Wireless Community Network" and published in the Journal of Peer Production, Issue n. 6: Disruption and the Law

2 Primavera De Filippi is a permanent researcher at the CERSA / CNRS / Université Paris II and faculty associate at the Berkman Center for Internet \& Society at Harvard Law School, where she is investigating the legal issues of decentralized online architectures.

${ }^{3}$ Félix Tréguer is $\mathrm{PhD}$ candidate in political science at the School for Advanced Studies in Social Sciences (CRH / EHESS) in Paris, researching on the consequences of the Internet for free speech and citizen empowerment in democratic regimes. He is also a legal analyst and founding member of La Quadrature $\mathrm{du}$ Net, an advocacy group promoting fundamental rights on the Internet
} 


\section{A short history of the Internet access market in Europe}

Since its early days, the Internet has followed a trend of emancipation. Already throughout the 1970s and 1980s, engineers and early hackers were experimenting with computers and exploring the potential of these new machines as communications devices. But it is only in the following years, as personal computing boomed and the computer networks spread, that efforts from civil society to democratize the use of these revolutionary technologies went viral. The creation of the World Wide Web in 1989 finally opened the door to widespread Internet use.

In the mid-1990's, the Internet access market boomed in Europe, partly because incumbent network operators had to open up the infrastructure rolled-out by state monopolies to small and innovative ISPs. In a context of rapid privatization, regulation promoted facility-based competition ${ }^{4}$ and new companies began laying down their own network infrastructure. This, along with the explosion of mobile telephony and the democratization of Internet access, made liberalization look like a success story: innovation in telecom services was dynamic and fast-paced, prices were low, and the number of subscribers surged.

Today, the EU regulatory framework is still often praised when compared to the situation in the US, where local Internet access markets are generally under a duopoly. Regulatory policies have indeed ensured some level of competition in European markets. But more in more, the two markets have a similar outlook: EU telecom policy has been unable to prevent the growing concentration of power in the telecommunications sector. Ex ante merger control by the EU Commission has typically been loose (Thatcher, 2014; Stoyanova, 2008), leading to de facto oligopolies in national or regional markets. Meanwhile, abuses of dominant positions by incumbent network operators are fairly common.

Overall, in the EU, policy targets in terms of broadband penetration and quality of service remain a distant reality: more than a third of European households still have no broadband access (39\%) and, in a country such as Greece, broadband penetration is as low a $56 \%$ (EU Commission, 2013). A fifth of EU citizens with no Internet access say they are deterred by the sheer cost of it (EU Commission, 2013): the cheapest available broadband offer can be as high as $€ 46.20$ in Cyprus, $€ 38.70$ in Spain or $€ 31.40$ in Ireland (EU Commission, 2014a). Meanwhile, users are not provided with the service they paid

4 Facility-based competition, or infrastructure-based competition, refers to the regulatory focus on creating competition between telecom firms that each have their own distinct network infrastructure for delivering end-user services, such as Internet access provision. 
for: on average, they only get $75 \%$ of the broadband speed they signed up for; $63 \%$ when they get it through ADSL rather than cable or fiber lines (SamKnows, 2013). The situation is usually much worse in rural areas. Meanwhile, telecom operators also have the technical ability and economic or regulatory incentives to hinder the autonomy of Internet users, for instance by violating the principle of Net neutrality.

The trend towards centralization, combined with economic incentives and regulations encouraging surveillance and control has led to the revival of more decentralized, citizencentric network architectures. This is illustrated, in recent years, by the deployment of Wireless Community Networks (WCN) — grassroots community networks, deployed at the local or regional level, managed by the community and for the community.

All across Europe, and beyond, there are currently a large number of grassroots community networks seeking to provide a decentralized alternative and more commonsbased approach to the current Internet infrastructure. Rather than being driven by profits like most of the large, highly capitalized Internet Service Providers (ISPs), WCN focus on the actual needs of its participants. While most of them are very limited in scope - and are therefore not widely heard of -, the most popular ones enjoy more than dozens of thousands of users. ${ }^{5}$

\section{Community networks and new power dynamics in telecom infrastructures}

Given the considerable investments required to set up an independent network infrastructure, and given the costs of purchasing wholesale access to last-mile landline networks from commercial operators, many grassroots community networks have decided to operate via wireless technologies, setting up network of peers sharing radio signals. Most of their network infrastructure consists of wireless radio equipment: Wi-Fi routers and antennas strategically distributed at different locations so as to maximize coverage. As a result, they can often provide a service of better quality than that which is generally available from commercial alternatives.

At the operational level, almost every grassroots community network tries to promote users' autonomy and fundamental rights to communication and privacy. As opposed to

5

For the purpose of this paper, we focused on a handful of groups, and in particular FreiFunk (Germany), Wlan Slovenija (Slovenia), Guifi.net (Spain) and Tetaneutral.net in Toulouse (France) - the latter is also a member of the FFDN, a federation of French grassroots networks initially spearheaded by the landline community network FDN. Other European WCN include Ninux (Italy), Funfeuer (Austria), the Athens Wireless Metropolitan Network (Greece), Djurslands.net (Denmark) and Czfree.net (Czech Republic). 
commercial ISPs blocking certain ports and censoring websites or content, community networks ardently protects Net neutrality. In several countries, small community networks are usually not bound by censorship orders issued by courts against illegal online content. In this regard, user autonomy and self-reliance is maximal when WCN are apprehended not just as part of the wider Internet but as autonomous local networks (or Intranets), allowing users to share information with other users connected to the same community network. Local networks also enable users to escape from the ubiquitous and pervasive surveillance that is occurring on the global Internet, as a result of privacyintrusive practices undertaken by traditional online operators. In particular, given the lack of a central authority regulating access to the network, it is in theory more difficult for anyone to assess the real identity of users connected to these networks.

Accordingly, WCN constitute, essentially, a political choice: by establishing a mix of social and relational ties between participants involved in the provision of the network infrastructure, they promote a more democratic and cooperative political system, with a more symmetrical and participatory governance structure (Bauwens, 2005). Besides, most of these grassroots community networks experiment with novel models of distributed governance relying on cooperation and sharing among a community of peers (from a dozen to tens of thousands participants), and that are reminiscent of commonsbased peer production schemes (Benkler, 2006).

From a political standpoint, WCN can be regarded as a counter-power to currently established power structures or incumbents. Following the typology of social movements drawn by Stefania Milan in her analysis of "emancipatory communication practices", we can infer three ways by which community networks could counteract existing power dynamics in the telecom sector.

One way is to address the issue from within the political system, as insiders, formally interacting with the power holders in order to make them support the deployment of community networks. Another solution is to fight the problem as outsiders, pressuring both regulators and incumbents from outside the political system, by means of protests, demonstrations and other campaigning tactics aimed at voicing dissent against the practices of commercial ISPs and against the lack of appropriate regulation for community networks.

Yet, most community networks do not properly qualify as what social movement scholars define as "insiders" (although they sometimes do interact with policy-makers), and much less as outsiders. Mostly, they fall within the third category - what Milan identifies as "beyonders". They acknowledge that law and regulation will always be late compared to practice and private ordering, and purport to influence the networked ecosystem by remaining beyond the political system. This objective is achieved by 
building self-organized, decentralized and citizen-owned communications networks and setting up alternative socio-political and technical arrangements as a substitute for the traditional top-down power dynamics typical of traditional institutions.

WCN can also be regarded as a potential source of competition to mainstream commercial ISPs. As we have seen, not only can WCN provide better services than commercial alternatives, they also adhere to specific ethical commitments and governance structures. As opposed to commercial providers, which often go counter to the interests of consumers by engaging in anti-competitive behaviors, WCN promote open and democratic values, such as Net neutrality and consumer protection. While they do not directly wage competition against traditional ISP, these nonprofit, community networks serve to increase diversity in the market for Internet access - thereby opening up the range of options available to citizens. In this sense, WCN constitute a form of grassroots, bottom-up regulation of established players that simply emerges from there being a viable (and more attractive) alternative to the dominant, commercial system. ${ }^{6}$

At this point in time, however, WCN cannot totally emancipate from traditional incumbents. Although they can be completely autonomous when they operate as closed local networks, most community networks eventually need to connect with the global Internet network. Uplink Internet access is achieved by linking the local network to one or several "Internet gateways" in charge of routing the traffic from and to global backbones. ${ }^{7}$ Here, potential bottlenecks resurface.

To obtain such an uplink to the Internet, community networks currently choose from a number of strategies. The first is to use upstream through traditional mainstream last-mile ISPs. Some WCN, like Freifunk in Berlin, prefers not to build any formal relationship with third party ISPs, and simply rely on the goodwill of community members (who are also subscribers of commercial ISPs) to share their commercial Internet connection so as to provide bandwidth and connectivity to the rest of the network.

When relying exclusively on the uplink connections of mainstream ISPs to provide a gateway to the Internet is not possible, or perhaps simply not reliable enough, WCN must establish a commercial relationship with transit ISPs. The transit market is generally much more competitive than the mainstream last-mile Internet access markets. Lesser

\footnotetext{
${ }^{6}$ In Berlin, for instance, Freifunk's popularity actually brought incumbent telecom operators to update their service agreements enabling subscribers to share their DSL connection to contribute bandwidth to the network.
}

7 An Internet gateway is all that is required to connect a particular network to an existing Internet connection. The gateway router will share bandwidth with other devices on the network from that connection. Multiple gateways can be deployed on the same network to provide additional bandwidth, as does for instance Tetaneutral.net. 
concentration creates a more diverse ecosystem where multinational firms, such as Cogent or Level 3, compete with smaller, local companies. Diversity drives both competition and cooperation, and allows grassroots community networks to escape the risk of abusive behaviors on the part of incumbent operators. For instance, in New York, the RedHook initiative is getting support from both medium-sized ISPs (such as Brooklyn Fiber) and a number of even smaller ones established in the area.

That being said, one cannot rule out the possibility of a transit operator exerting control over, and even disconnecting, a community network. To the extent that in some markets (in both urban and rural areas) a few large telecom operators retain the ability to filter, censor, monitor, discriminate online communications, or simply refuse to interconnect, the need for uplink leads to the emergence of new bottlenecks that replicate the problems that community networks aimed to address in the first place.

To meet that challenge, some activists have begun to organize: the goal is for community networks to collectively acquire more independence and more bargaining power in the various markets in which they operate, and promote their philosophy in the face of the conflicting value systems of commercial telecom operators who might engage in predatory practices. A first experiment of this kind was carried on in 2012, when community networks FunkFeuer from Austria, NEDWirelles from Croatia, and Wlan Slovenija established a wireless backbone spanning across geographical borders to create a direct link between them. As the number of mesh networks deployed over the world grow, the potential for establishing a global and independent network infrastructure that abides to the founding principles of the Internet network will also increase.

\section{Regulatory framework favoring commercial players at the expense of WCN}

Despite their potential in fostering public interest goals in telecom policy, regulators have so far failed to support the efforts of community networks. More often than not, public policy actually puts important hurdles on their way.

The most striking example of such hurdles relates is that several community networks have been precluded from using public broadband networks funded with taxpayers' money. In France for instance, many local governments invested in rolling-out fiber networks in both urban and rural areas. These networks are built and managed by a private company contracted by the public authority, which leases access to traditional access providers that sell Internet access offers to subscribers. Yet, the fee charged to access the network is designed for big commercial ISPs, and is often prohibitive for nonprofit grassroots community networks.

Another other major problem of current telecom policies for $\mathrm{WCN}$ is the issue of 
spectrum management. Again, regulatory capture by commercial interests leads to regulatory choices that systematically overlook the potential of more flexible and citizencentric policies. The recent allocations so-called "digital dividend" (i.e. the frequencies left vacant by the switch from analog to digital television) is a textbook case. In France, for instance, it was proposed to use part of the spectrum dividend to create new digital TV channels and develop mobile television as well as digital radio (neither of these two technologies has taken off thus far). The remaining half of these frequencies for the lower UHF bands (sought-after because of their long-range propagation) was then auctioned off to telecom operators for their $4 \mathrm{G}$ mobile Internet access.

In the process, one option has, however, never been considered: extending "unlicensed" access to some of these frequencies, effectively turning them into a commons open for all to use. Long thought to be unreasonable because of the risk of radio interferences, opening up the spectrum to multiple, non-coordinated radio users has actually been experimented on a worldwide basis more than a decade ago for the Wi-Fi frequencies. Needless to say, it has proved to be a very wise policy choice.

Against the backdrop of traditional economic theory, open spectrum policies suggest that commons-based approach to many-to-many communication infrastructure can actually work in practice. Through packet switching, best-effort delivery, as well as innovative radio transmission and bandwidth management's techniques, Wi-Fi has successfully verified Ostrom's claim that users themselves and ad hoc technical standards can create and enforce rules that mitigate the over-exploitation of the commons (Ostrom, 1990). In many regards, though property-based allocations of spectrum and exclusive licensing still have the upper hand, they have often come short of fostering public interest goals, for instance by causing a very significant underutilization of this public resource. ${ }^{8}$

8 First, exclusive licensing have led to anti-competitive behaviors by spectrum owners, or favored certain technologies over potentially more promising ones. For example, several countries grant exclusive licenses to established commercial players providing Internet access through WiMAX or satellite, and even subsidize them. Second, such schemes have proved to encourage underutilization of the resource in the name of avoiding congestion, thus creating artificial scarcity of frequency bands. Many spectrum owners, be they the military or commercial operators (again, satellite or WiMAX come to mind) own important portions of spectrum but do not actually make full use of it, thus crowding out other technologies and potential uses of social value. TV and radio broadcasters also leave significant gaps between their respective channels (these so-called "white spaces") acting as buffers to avoid interference - thereby leaving many frequencies unused in the valuable UHF bands. Combined together, these phenomena bring underutilization to stunning levels: a recent study conducted for the EU Commission finds that, in Paris, the average spectrum use is as low as $7,7 \%$ of the $400 \mathrm{MHz}-3 \mathrm{GHz}$ bands, while the average spectrum utilization rate in Europe is under 
Moreover, not only does the regulatory focus on exclusive licensing create an enormous opportunity cost by favoring established players over innovative new-entrants (such as community networks), it has even been argued by human rights NGOs that it may actually breach the international law on freedom of expression (Article 19, 2005).

Meanwhile, despite the successes of Wi-Fi, unlicensed access to spectrum remains marginal and regulators have a tendency to ignore WCN's spectrum needs. Guifi.net and Freifunk, for instance, report having a hard time maintaining the quality of their network because of the saturation of the $5 \mathrm{GHz}$ frequency bands. ${ }^{9}$ Another issue for $\mathrm{WCN}$ is linked to the topography of their environment: Wi-Fi bands have some important technical limitations, in particular in terms of propagation, and signals are easily blocked by buildings or trees. WCN are thus faced with the choice of either renouncing to create a new radio link in a given location, or push the emission power levels beyond the legal limits to overcome these obstacles.

\section{Towards a new public policy for the network commons}

Much can be done at the regulatory level not only to lift the technical, legal and policy hurdles that community networks run into, but also to actively support them. Several elements presented in the course of this paper - from regulatory capture to the impressive results achieved by these small nonprofit citizen groups - show that this is both an urgent and sound policy move.

First, there is a range of regulations that make WCN's very existence significantly and often unnecessarily difficult. In a country such as Belgium for instance, the registration fee that telecom operators must pay to the NRA is relatively high, whereas in France, Spain or Germany, it is free - which may explain why the movement is much more dynamic in these countries. It is, therefore, all the more important that registration processes be harmonized at the EU level, and, in particular, that they remain free for nonprofit networks.

Second, several laws seek to prevent the sharing of Internet connections amongst several users by making people responsible (and potentially liable) for all communications made through their Wi-Fi connection. This is the case in France, for

10\% (Forge \& al., 2012).

9 WCN theoretically could be allowed to use the other portion of spectrum by NRAs. Yet, they also refrain from doing so. Except for the $2,4 \mathrm{GHz}$ and $5 \mathrm{GHz}$ licenseexempt bands were high demand has driven prices down, radio networking remains a niche market for manufacturers of radio transmitters, and the gear necessary to deploy wireless networks in other bands is costly. Community networks generally cannot afford the price. 
instance, where the 2009 three-strikes copyright law against peer-to-peer file-sharing also introduced a tort for improperly securing one's Internet connection against unlawful activity on the part of a third party. As a result, many community networks willing to establish open Wi-Fi networks in public spaces, such as parks and streets, refrain from doing so out of legal insecurity. It is our view that, even though connection sharing might sometimes make law enforcement more difficult by allowing many unrelated users to share the same IP address, this drawback is more than compensated by the benefits brought about by the deployment of open wireless networks.

Third, it is not just Internet wireless access points that can be shared, but also the intangible infrastructure on which radio signals travel. As we have seen, unlicensed spectrum is a key asset for community networks to set up affordable and flexible lastmile infrastructure, but it is currently very limited. In the US, the FCC has initiated promising policies in that field. ${ }^{10}$ But for the moment, the EU has shied away from similar moves. In 2012, the EU adopted its first Radio Spectrum Policy Programme (RSPP). During the legislative process, the EU Parliament voted in favor of ambitious amendments aimed at opening more spectrum to unlicensed uses. ${ }^{11}$ Even if some of these amendments were later scrapped by national governments, the final text still calls for member states and the European Commission to "assess" the "need for and feasibility of extending the allocations of unlicensed spectrum" in the Wi-Fi bands, while also voicing tepid support for mesh networks by stressing their potential to foster access to the global Internet. As EU lawmakers were working on the RSPP, a study commissioned by the EU Commission also called for a new $100 \mathrm{MHz}$ of license-exempt bands as well as for higher power output limits in rural areas to reduce the cost of broadband Internet access deployment. ${ }^{12}$ Since then, however, EU work on unlicensed spectrum and on flexible

10 For the past years, through several regulatory moves, the FCC has been opening UHF "white spaces" to unlicensed uses. It has also started expanding the so-called "Unlicensed National Information Infrastructure" by adding $195 \mathrm{MHz}$ of spectrum in the $5 \mathrm{GHz}$ band and increase the permissible power for radio transmitters in these bands. See Farivar, C. (2014, March 31). More Wi-Fi is better: FCC expands use of $5 \mathrm{GHz}$ spectrum. Ars Technica. Retrieved May 11, 2014, from http://arstechnica.com/informationtechnology/2014/03/more-wi-fi-is-better-fcc-expands-use-of-5-GHz-spectrum/

11 La Quadrature du Net. (2011, May 11). EU Parliament Adopts Open Wireless Communications Policy. LaQuadrature.net. Retrieved May 12, 2014, from $\mathrm{http}: / /$ www.laquadrature.net/en/eu-parliament-adopts-open-wireless-communicationspolicy

12 For giving unlicensed access to another $100 \mathrm{MHz}$ of spectrum bands, the report suggested that half of these should be in the $1 \mathrm{GHz}$ bands and the other one at 1,4 GHz. To avoid underutilization, the report also calls on policy-makers to suspend exclusive use 
authorization schemes that would be more accessible to community networks has stalled. In a communication released in September 2012, the EU Commission failed to announce any concrete action to expand unlicensed use of the spectrum (European Commission, 2012). At the national level too, there is unfortunately no policy change in sight.

Fourth, networks built with taxpayers' money could also be treated as a commons, and as such should remain free from corporate capture. Regulators should ensure that nonprofit community networks can access publicly-funded and subsidized physical infrastructures without unnecessary financial or administrative hurdles. Accordingly, they should review existing policies and current practices in this field, providing transparent information to map publicly funded networks, and mandate rules to allow community networks to use these on a preferential basis. ${ }^{13}$

Of course, countless other policy initiatives can help support grassroots networks, such as small grants and subsidies to help these groups buy servers and radio equipment, communicate around their initiative, but also support their research on radio transmission, routing methods, software or encryption (Shaffer, 2013).

Yet, all these proposed policies point to an overarching issue, namely the need to democratize telecom policy and establish procedures that can institutionalize existing and potential grassroots community networks. In many countries, such as Spain or Italy, even though city councils may occasionally actively support these organizations to the extent that they provide better Internet access to their citizens, regional governments and national regulators have so far largely neglected them.

Given the revival of community networks in the past years, it is not enough for regulatory authorities to treat citizens as mere consumers by occasionally inviting consumer organizations at the table. Regulators and policy-makers need to recognize that the Internet architecture is a contested site, and that citizen groups across Europe and beyond are showing that for the provision of Internet access, commons-based forms of

of specific channels whenever the use of that spectrum is consistently below a level justifying any form of exclusivity (Forge \& al., 2012). In France, where WiMAX roll-out has been so slow that the NRA eventually notified the corresponding licensees that they were in breach of their obligations, such a measure could lead to many more channels being opened up for shared or even unlicensed use, for instance to community networks.

13 On very-fast broadband roll-out, our interviewees also pointed to the need to reorient both public and private investments in fiber-optic last-mile networks where they are most needed, that is in rural communities where decent broadband is crucially lacking, rather than in already well-connected urban areas where there is usually less demand for higher speeds. They also called on regulators to better coordinate so that any public work being carried to roll-out fiber-optic cables that can then be used to expand and improve Internet access. 
governance are not only possible but that they also represent effective and viable alternatives to the most powerful telecom operators. Their participants have both the expertise and legitimacy to take an integral part in technical and legal debates over broadband policy in which traditional, commercial ISPs are over-represented. They can bring informed and dissenting views to these debates, and eventually help alleviate regulatory capture.

But democratizing telecom policy is not the sole responsibility of institutional actors. If regulators are not ready to listen, community networks must organize politically and pressure them to do so. Indeed, many community networks are working to form a more cohesive and powerful group to discuss legislative issues and advocate regulatory reforms. Of course, a potential problem for sustaining political engagement is the fact that community networks are often run by volunteers whose lack of time and resources may sometimes make it difficult form them to participate as actively as the full-time and well-resourced lobbyists of incumbent actors. But overtime, as the movement grows, it may be able sustain its engagement with public authorities, especially if the latter adapts and establish ad hoc contact channels and remote participation mechanisms. Going back to the typology of political action, direct engagement with policy-makers constitutes a more "insider" strategy that might well be worth pursuing.

\section{References}

Ackerman, L. (2011, March 9). Internet "Kill Switch" Legislation: Can Obama Turn Off the Internet? The BTLJ Bolt. Retrieved May 16, 2012, from http://btlj.org/2011/03/09/internet-kill-switch-legislation-can-obama-turn-off-theinternet/

Akyildiz, I. F., Wang, X., \& Wang, W. (2005). Wireless mesh networks: a survey. Computer networks, 47(4), 445-487.

Albert, S. (2013). The Case of Chapleau Network: Why Community Wireless Networks Fail? In A.

Article 19. (2005). The legitimacy of license requirements for the use of wireless communications devices. Retrieved April 16, 2014, from http://www.wsiscommunity.org/pg/file/read/1674/the-legitimacy-of-licence-requirements-for-theuse-of-wireless-communications-devices

Asghari, H., Eeten, V., Van Eaten, M., Bauer, J. M., \& Mueller, M. (2013). Deep Packet Inspection: Effects of Regulation on Its Deployment by Internet Providers. 
Presented at the 41st Research Conference on Communication, Information and Internet Policy, Rochester, NY: Social Science Research Network. Retrieved from http://papers.ssrn.com/abstract=2242463

Ball, J., Harding, L., \& Garside, J. (2013, August 2). BT and Vodafone among telecoms companies passing details to GCHQ. The Guardian. Retrieved from http://www.theguardian.com/business/2013/aug/02/telecoms-bt-vodafone-cablesgchq

Barlow, J. P. (1996, February 9). A Cyberspace Independence Declaration. Retrieved from https://w2.eff.org/Censorship/Internet_censorship_bills/barlow_0296.declaration

Bauwens, M. (2005). P2P and Human Evolution: Peer to peer as the premise of a new mode of civilization. Ensaio, rascunho, 1.

Belli, L., De Filippi, P. (2014). Network Neutrality: An Ongoing Regulatory Debate. Second Report of the Dynamic Coalition on Network Neutrality, IGF 2014.

Benkler, Y. (2006). The Wealth of Networks. Yale University Press.

BEREC (Body of European Regulators for Electronic Communications), 2012, “An assessment of IP-interconnection in the context of Net neutrality", Draft report for public consultation

Bernal, P. (2014). Internet privacy rights: rights to protect autonomy. Cambridge University Press.

Boston Consulting Group. (2013). Reforming Europe's Telecoms Regulation to Enable the Digital Single Market. Retrieved from https://www.etno.eu/news/etno/2013/219

Bradwell, P., Craggs, G., Cappuccini, A., \& Kamenova, J. (2012). Mobile Internet censorship: what's happening and what we can do about it (LSE Media Policy Project \& Open Rights Group). London. Retrieved from https:/www.openrightsgroup.org/ourwork/reports/mobile-internet-censorship:whats-happening-and-what-we-can-do-about-it

Cambini, C., \& Rondi, L. (2011). Independence, Investment and Political Interference: Evidence from the European Union (EU Working Papers). Florence School of Regulation, Robert Schuman Center for Advances Studies.

Christman, J. (2011). Autonomy in moral and political philosophy..Stanford Encyclopedia of Philosophy online.

Cisco. (2013, May 29). Cisco Visual Networking Index: Forecast and Methodology, 2012-2017. Retrieved May 10, 2014, from http://www.cisco.com/c/en/us/solutions/collateral/service-provider/ip-ngn-ip-nextgeneration-network/white_paper_c11-481360.html

Clark, D. (1992). A Cloudy Crystall Ball, Visions of the Future. In Proceedings of the 
24th Internet Engineering Task Force (p. 539). Cambridge, MA. Retrieved from http://www.ietf.org/old/2009/proceedings/prior29/IETF24.pdf

Coase, R. H. (1959). The Federal Communications Commission. Journal of Law and Economics, 2, 1-40.

Coleman, G. (2005). Indymedia's Independence: From Activist Media to Free Software. Multitudes, 21(2), 41-48.

Deibert, R. J. (2013). Black Code: Inside the Battle for Cyberspace. Random House.

European Commission. (2012). Communication on promoting the shared use of radio spectrum resources in the internal market. Brussels.

European Commission. (2013). e-Communications Household Survey (Special Eurobarometer No. 396). Brussels: EU Commission. Retrieved from http://ec.europa.eu/digital-agenda/en/news/special-eurobarometer-396-ecommunications-household-survey

European Commission. (2014a). Broadband access in the EU: Situation at 1 July 2013. Retrieved from ec.europa.eu//digital-agenda/en/news/broadband-access-eu-situation-1july-2013

European Commission. (2014b). EU Anti-Corruption Report (No. COM(2014) 38). Brussels.

Feenberg, A. (1995). Subversive Rationalization: Technology, Power and Democracy. In A. Hannay \& A. Feenberg (Eds.), Technology and the politics of knowledge (pp. 322). Indiana University Press.

Felten, E. (2014, April 22). Mesh Networks Won't Fix Internet Security. Freedom to Tinker. Retrieved May 6, 2014, from https://freedom-totinker.com/blog/felten/mesh-networks-wont-fix-internet-security/

Follorou, J. (2014, March 20). Espionnage : comment Orange et les services secrets coopèrent. Le Monde.fr. Retrieved from http://www.lemonde.fr/international/article/2014/03/20/dgse-orange-des-liaisonsincestueuses_4386264_3210.html

Giurgiu, I., Riva, O., Juric, D., Krivulev, I., \& Alonso, G. (2009). Calling the cloud: enabling mobile phones as interfaces to cloud applications. In Middleware 2009 (pp. 83-102). Springer Berlin Heidelberg.

Goldsmith, J., \& Wu, T. (2006). Who Controls the Internet?: Illusions of a Borderless World. Oxford University Press, USA.

Habermas, J. (1991 [1962]). The Structural Transformation of the Public Sphere: An Inquiry Into a Category of Bourgeois Society. MIT Press.

Hasan, S., Ben-David, Y., Fanti, G., Brewer, E., \& Shenker, S. (2013). Building Dissent Networks: Towards Effective Countermeasures against Large-Scale Communications Blackouts. In 3rd USENIX Workshop on Free and Open 
Communications on the Internet. Washington DC. Retrieved from https://www.usenix.org/conference/foci13/workshop-program/presentation/hasan

Johnson, D. R., \& Post, D. G. (1997). And How Shall the Net Be Governed?: A Meditation on the Relative Virtues of Decentralized, Emergent Law. In B. Kahin \& J. H. Keller (Eds.), Coordinating the Internet (pp. 62-91). Cambridge, MA, USA: MIT Press.

Juniper Research. (2013, April 10). Mobile Data Offload \& Onload Wi-Fi, Small Cell \& Carrier-Grade Strategies 2013-2017. Retrieved May 10, 2014, from http://www.juniperresearch.com/reports/mobile_data_offload_\&_onload

Kirk, A. (2002). "Machines of Loving Grace": Alternative Technology, Environment and the Counterculture. In P. Braunstein \& M. W. Doyle (Eds.), Imagine Nation: The American Counterculture of the 1960s and '70s (pp. 353-378). New York: Routledge.

La Quadrature du Net. (2012). Commentaires sur le projet de rapport de l'Arcep au Parlement et au Gouvernement sur la neutralité de l'Internet. Retrieved from http://www.laquadrature.net/files/LQDN-20122106-

Commentaires_Pr\%C3\%A9Rapport_Arcep_Neutralit\%C3\%A9.pdf

Laffont, J.-J., \& Tirole, J. (1991). The Politics of Government Decision-Making: A Theory of Regulatory Capture. The Quarterly Journal of Economics, 106(4), 10891127.

Laffont, J.-J., \& Tirole, J. (2001). Competition in Telecommunications. MIT Press.

Lessig, L. (1999). Open Code and Open Society: Values of Internet Governance. Chicago-Kent Law Review, 74(102).

Levine, M. E. (1990). Regulatory capture, public interest, and the public agenda: toward a synthesis. Yale School of Organization and Management.

Licklider, J. C. R., \& Taylor, R. (1968). The Computer as a Communication Device. Science and Technology.

Loveluck, B. (2012). Freedom Through Information: A Political Genealogy of Informational Liberalism and Self-Organization on the Internet. $\mathrm{PhD}$ thesis. EHESS, Paris.

McChesney, R. W. (2013). Digital Disconnect: How Capitalism is Turning the Internet Against Democracy. The New Press.

McNamee, J. (2011). The slide from self-regulation to corporate censorship. Brussels: European Digital Rights.

Milan, S. (2013). Social Movements and Their Technologies: Wiring Social Change. Palgrave Macmillan.

Mintcheva, S. (2009, October 29). The Chamber of Commerce is not and should not be immune to political satire | National Coalition Against Censorship. National 
Coalition Against Censorship. Retrieved from http://ncac.org/blog/the-chamber-ofcommerce-is-not-and-should-not-be-immune-to-political-satire/

Mueller, M. L. (2010). Networks and States: The Global Politics of Internet Governance. MIT Press.

Musiani, F., Schafer, V., \& Le Crosnier, H. (2013). Net neutrality as an Internet Governance Issue: The Globalization of an American-Born Debate. Revue Française D'études Américaines, $n^{\circ}$ 134(4), 47-63.

Ostrom, E. (1990). Governing the commons: The evolution of institutions for collective action. Cambridge university press.

Pool, I. de S. (1984). Technologies of Freedom. Belknap Press of Harvard University Press.

SamKnows. (2013). SamKnows study on Internet speeds. Retrieved from https:/ec.europa.eu/digital-agenda/en/news/quality-broadband-services-eusamknows-study-internet-speeds

Shaffer, G. (2013). Lessons Learned from Grassroots Wireless Networks in Europe. In A. Abdelaal (Ed.), Social and Economic Effects of Community Wireless Networks and Infrastructures: (pp. 236-254). IGI Global.

Starr, P. (2004). The creation of the media: political origins of modern communications. Basic Books.

Stoyanova, M. (2008). Competition Problems in Liberalized Telecommunications: Regulatory Solutions to Promote Effective Competition. Kluwer Law International.

Sutherland, E. (2012). Corruption in telecommunications: problems and remedies. Info, 14(1), 4-19.

Thatcher, M. (2014). European Commission merger control: Combining competition and the creation of larger European firms. European Journal of Political Research, 53(3), 443-464.

Tréguer, F. (2013). Insurgent Citizenship on the Internet: Pushing Back the Limits of the Public Sphere. In Non-Compliance to the Rules and Disobedience Towards the Law. International Congress of the Research Committee on Sociology of Law, Toulouse.

Turner, F. (2006). From Counterculture to Cyberculture: Stewart Brand, the Whole Earth Network, and the Rise of Digital Utopianism. University of Chicago Press.

Villeneuve, N. (2010). Barriers to Cooperation: An Analysis of the Origins of International Efforts to Protect Children Online. In R. Deibert, M. Haraszti, J. Palfrey, Zittrain, \& R. Rohozinski (Eds.), Access Controlled: The Shaping of Power, Rights, and Rule in Cyberspace. MIT Press.

Willetts, P. (2010). NGOs networking and the creation of the Internet. In Non- 
Governmental Organizations in World Politics: The Construction of Global Governance (pp. 114-143). Taylor \& Francis US.

Wu, T. (2010). The Master Switch: The Rise and Fall of Information Empires. Knopf.

Zhang, W., Wang, Z., Das, S. K., \& Hassan, M. (2007). Security issues in wireless mesh networks. In Wireless Mesh Networks (pp. 309-330). Springer US.

Zhang, Q., Cheng, L., \& Boutaba, R. (2010). Cloud computing: state-of-the-art and research challenges. Journal of internet services and applications, 1(1), 7-18

Zittrain, J. (2008). The Future of the Internet - And How to Stop It. Yale University Press. 